\title{
Evaluating the Effects of an R\&D Policy Mix of Subsidies and Tax Credits
}

\author{
Daniel NEICU ${ }^{1}$
}

\begin{abstract}
This paper studies the additionality of a policy mix of $R \& D$ subsidies and wage-based tax credits on firms' spending on basic research, applied research, and on development activities. Using non-parametric matching and instrumental variables estimations on a rich dataset of $R \& D$-active companies, the results show that tax credits and subsidies have substantially different effects on firms' $R \& D$ budgets. First, while tax credits alone increase private $R \& D$ spending, subsidies only do so when they are used together with tax credits. Second, tax credits seem to outperform subsidies, showing positive effects on all types of $R \& D$. Subsidies only increase research spending when mixed with tax credits, and have no effect on development spending. These results have interesting implications for $R \& D$ policy design and $R \& D$ management.
\end{abstract}

KEYWORDS: $R \& D$, additionality, tax credits, subsidies, policy mix.

JEL CLASSIFICATION: $D 01, D 03, D 04, D 78$.

\section{INTRODUCTION}

The role of public intervention in private $R \& D$ stems from the link between research, innovation and economic growth (Mansfield, 1972). Underinvestment in R\&D hinders growth, which incentivises governments to support firms' efforts in research and development to achieve a social optimum of innovation activity. Underinvestment in R\&D is based on two market failure arguments (Arrow, 1962). First, because knowledge is a non-rival and nonexclusive good, firms cannot fully appropriate the returns on their R\&D investments; this stems from knowledge having high fixed costs of production and low marginal costs of utilisation. Second, uncertainty is a defining characteristic of innovative activity. When firms engage in $R \& D$, they cannot fully predict the output by the inputs they employ. If economic actors are risk averse, they will discriminate against risky projects (Arrow \& Lind, 1970). The latter argument is aggravated for $R \& D$ projects that are farther away from the market, as is the case for basic and applied research, compared with product or process development. As uncertainty about returns is higher for the former, firms encounter more barriers to finance these projects externally and need to rely more on internal funds (Czarnitzki \& Hottenrott, 2011).

Whichever the reason for the market failure, governments saw the need to provide incentives to firms to bridge the gap between the private and social returns to investment in R\&D. This has usually been done by directly subsidising research projects. R\&D grants have the advantage of directly addressing market failures by allowing policy makers some control over

\footnotetext{
${ }^{1}$ European Commission, Brussels, Belgium, and the Department of Strategy, Innovation \& Entrepreneurship, University of Leuven, Belgium. Email: daniel.neicu@ec.europa.eu.

The opinions expressed are those of the author only and should not be considered as representative of the European Commission's official position.
} 
which type of research they finance. However, information asymmetries, bureaucracy or political pressure can result in the mismanagement of public funds and an aggravation of the market failure that required intervention in the first place. More recently, countries have started to implement various systems of tax credits for firms engaged in R\&D. Among OECD member states, the percentage of governments offering some form of tax credits doubled between 1995 and 2011, reaching 75\% of countries implementing such policies (OECD, 2013). The attractiveness of tax credits to governments stands mainly in their administrative simplicity via lower information asymmetries, while also providing firms with a more predictable policy than subsidies (Haegeland \& Møen, 2007a).

With the increasing use of tax credits alongside subsidies comes the risk that different policies might crowd each other out, thus the need to properly assess the interactions between them. Most empirical studies to date assess solely the impact of one of these policies rather than their combined effects. ${ }^{i}$ However, a growing literature on the combined use of different policies is emerging. On the one hand, some studies compare the effects of tax credits with those of subsidies on firms' R\&D expenditure (Haegeland \& Møen, 2007b; Dumont, 2017; Guerzoni \& Raiteri, 2015; Marino et al., 2016). On the other hand, there are studies that distinguish the impact of subsidies on either research or development spending (Czarnitzki, Hottenrott, \& Thorwarth, 2011; Hottenrott, Lopes Bento \& Veugelers, 2014).

Therein the contribution of this paper. It evaluates whether subsidies and tax credits increase R\&D spending in firms that are using either measure or combining them in a policy mix. Moreover, the analysis goes beyond the classical input additionality approach and studies if the two policies have different effects on basic research, applied research and development activities.

In some respects, it complements research by Neicu et al. (2016), who analyse a survey of a subset of tax credit users from Belgium. Their analysis of self-reported Likert-scale survey answers provides a first view of how subsidies can affect firms already using tax credits, albeit while answering different questions regarding the scale and scope of R\&D projects. My paper differs in a number of ways - including the research questions and data used to answer them - and brings more robust evidence on both input and behavioural additionality of subsidies and tax credits through the use of instrumental variables and matching methods. ${ }^{\text {ii }}$

I find strong evidence of input additionality from tax credits used alone or combined with subsidies, but cannot dismiss crowding out for subsidies alone. Moreover, I show evidence that both policies induce a behavioural change away from development and towards research. From an econometric perspective, I mitigate possible bias arising from hidden treatments and selection of firms into programmes, two hot issues in contemporary policy evaluation research.

The paper is organised as follows. Section 2 reports existing literature on the topic. Section 0 describes the data and identification methods. Section 4 reports the results, and Section 5 concludes.

\section{EXISTING THEORY AND EVIDENCE}

\subsection{R\&D grants and tax credits as separate policies}

Positive additionalityfromsubsidies on firms' R\&D expenditure has been found in Germany (Czarnitzki \& Licht, 2006), France (Duguet, 2004), Flanders (Aerts \& Schmidt, 2008; 
Czarnitzki \& Lopes-Bento, 2013), Italy (Carboni, 2011) and Spain (González \& Pazó,

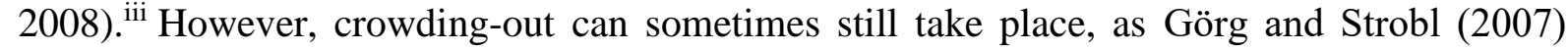
show was the case of larger Irish firms.

Regarding tax credits, Hall and Van Reenen (2000) found in a meta-analysis that most results point towards a dollar-for-dollar increase in firms' $R \& D$ spending due to tax credits, and more recent studies have generally confirmed the positive effects (Haegeland\&Møen, 2007a; Corchuelo \& Martínez-Ros, 2009; Duguet, 2012; Czarnitzki, Hanel, \& Rosa, 2011). Lokshin and Mohnen (2012) perform an analysis of the Dutch R\&D tax incentive introduced through the Wage Tax and Social Insurance Act. The level-based tax deduction is applied to R\&D labour costs, similarly to the Belgian system analysed in the current paper. They find that the Dutch programme stimulates $R \& D$ investment and the bang-for-the-buck is larger for small firms. Ientile and Mairesse (2009) however conclude, after analysing over 30 studies on the effectiveness of tax credits, that evidence is scattered based on the methodology used and on the design of the incentive scheme itself.

\subsection{The policy mix}

The lack of empirical evidence of the interaction between direct and indirect - and, more generally between different levels of - support for R\&D has been signalled multiple times in recent years (Flanagan et al., 2011; Aranguren et al., 2014). The consensus so far seems to be that different policies may interact with one another (Montmartin \& Herrera, 2015; Martin, 2016). The reasons to expect any interaction stem both from the characteristics of direct and indirect support and from the possibility of their simultaneous use. Whereas subsidies allow granting agencies some form of control over how firms use the public funds, tax credits impose lower administrative costs on both the firm and policy makers, while allowing firms more freedom in their choice of R\&D projects (Montmartin \& Herrera, 2015). Receiving a grant can also act as a signal to other financing bodies and thus indirectly increase firms' attractiveness to venture capitalists or private lenders (Takalo \& Tanayama, 2010). Furthermore, grants are usually earmarked for use within a specific R\&D project, while tax incentives can be redirected to non-R\&D activities. Clearly, different policies not only have different goals, but also function in different ways at managerial level.

Some recent research has focused on how firms simultaneously use R\&D subsidies and tax credits, either by measuring the impact on private R\&D inputs (Haegeland \& Møen, 2007a; Carboni, 2011), on innovative output (Bérubé \& Mohnen, 2009), or by exploring the drivers behind the choice of each policy (Busomet al., 2014). Studies have focused on comparing the effects of subsidies and tax credits, and most have found that input additionality from tax credits is larger than from subsidies (Haegeland \& Møen, 2007b; Hall \& Maffioli, 2008; Carboni, 2011). Conversely, Westmore (2013) reports that subsidies seem to have greater impact than tax credits in a panel of 19 OECD countries. Finally, firms combining direct and indirect support have been shown to experience greater additionality on R\&D expenses than single-policy users (Guerzoni \& Raiteri, 2015; Marino et al., 2016). One caveat when analysing policy mixes is that apparent substitution effects between different policies might in fact be a reduction in bias due to controlling for 'hidden treatments'. That is, when analysing single policies, estimated effects are usually larger than when accounting for simultaneous use(Guerzoni \& Raiteri, 2015), an issue that most previous studies have not tackled.

Dumont (2017) finds some evidence that Belgian R\&D subsidies and tax exemptions are substitutes, although the magnitude of the effect is limited. Because his data includes subsidies received as of 2001 and tax exemptions started in 2006, there is a strong possibility 
that the positive additionality effect of subsidies is driven by the period before the wage-based tax credits were introduced in 2006. In this sense, the interaction between the two support measures may not be completely captured in his panel.

I use both matching and instrumental variable models to verify the robustness of my results, as Dumont (2017) states that "results on the impact of public support appear to depend on the econometric specification and estimation procedure that is considered.

\subsection{Effects of R\&D support on basic and applied research, and on development spending} When evaluating public policy, it is oftentimes forgotten that $R \& D$ is not a monobloc. The market failures inherent to R\&D might affect disproportionately each of its components. Outcome uncertainty plays a bigger role when firms engage in basic research, as the intrinsic characteristics of this activity make it more prone to risk and distance it from a potential market. Financing from external sources basic research is thus more difficult than projects which are closer to the market, i.e. applied research and development projects. Furthermore, knowledge created in basic and applied research is harder to appropriate than knowledge created by development activities. Coupled with the larger contribution of basic research to innovation, this translates into private rates of return from research being smaller than the social rates of return (Rosenberg, 1990; Mansfield, 1991).

Research activities are more sensitive to operating liquidity than development activities, as firms need to rely more on internal funds to finance basic and applied research. Thus cashstrapped firms will have less resources for research, whereas they should find it easier to finance development through market loans (Czarnitzkiet al., 2011). In this vein, the Flemish regional government in Belgium has devised specific policies to directly subsidise firms' research and development activities separately. Hottenrottet al. (2014) analyse this framework and find that the policy has direct effects on private spending - i.e. research (development) subsidies increase private spending on research (development) - but also cross-effects, from research grants to private development expenditure and vice-versa.

In earlier work, Clausen (2009) showed that subsidies for projects farther from the market do stimulate additional spending in Norwegian firms, while those granted for projects closer to the market crowd out private funding.

Tax credits can usually be freely spent by firms, and are more likely to be used to finance projects with high private rates of return (David, Hall, \& Toole, 2000; Montmartin \& Herrera, 2015). Czarnitzkiet al. (2011) evaluate the Canadian tax credit system and bring empirical support for this argument.

They find that firms that use tax credits do invest more in $R \& D$, but some investment is in short-term projects that lead to incremental innovations. It can thus be argued that firms use tax credits to invest more on development, rather than basic or even applied research. On the other hand, fiscal exemptions can also finance marginal projects which might be deemed too risky to be subsidized.

The Belgian tax credit I analyse is granted to firms who employ highly-skilled researchers, which are more prone to engage in basic and applied research than development. Dumont et al. (2015) find that using the tax credit induces an increase of PhD-holders in firms' research departments. Considering this, it could well be the case that the tax credit increases research 
rather than development spending. Neicu et al. (2016) have shown that there are important differences in how tax credit recipients respond to also receiving subsidies.

They conclude that grants increase any effects that tax credits may have on the speed, scale and composition of R\&D projects. However, their analysis does not allow any conclusion on the additionality of tax credits or the policy mix themselves, as their control group comprises tax credit-only users and the treatment group policy mix users. The current paper diverges significantly from Neicu et al. (2016) in a few ways. First, I use a different and much more comprehensive dataset of Belgian firms, based on the entire population of R\&D-active firms in Belgium, and complemented by financial and fiscal data from federal authorities.

This allows me to define control groups of firms that do not receive any support, thus correctly measure additionality on R\&D. Second, I make use of data on the actual amounts granted to firms and amounts spent on $R \& D$, rather than mere binary indicators.

Third, I analyse the effects of public support on actual R\&D expenditure, rather than on Likert-scale survey answers regarding the scale and scope of R\&D projects. And finally, I use more complex econometrical models to robustly identify additionality effects.

\section{DATA AND METHOD}

\subsection{R\&D subsidies and tax credits in Belgium}

R\&D subsidies in Belgium are granted by regional authorities of the three administrative regions - Brussels, Flanders and Wallonia. Firms pass through a selection procedure at the end of which projects are either funded or rejected. The Region of Flanders subsidises research, development or mixed (R\&D) projects to varying degrees, offering extra incentives for SMEs, as do the other two regions. Moreover, Flanders and Brussels also fund feasibility studies, while Flanders and Wallonia target specific industries based on economic needs.

Tax credits are a federal measure which applies to all firms within the country. The specific tax credit I analyse is a partial wage withholding tax exemption on researchers' salaries and has been introduced in October 2005, at first only for researchers working on collaborative R\&D projects with universities or other research centres. In 2006 it has been extended to all employees with a $\mathrm{PhD}$ degree in science and all $\mathrm{R} \& \mathrm{D}$ personnel employed in young innovative companies (YICs), and from 2007 it is applicable to researchers with a Master degree too. It is thus somewhat different from the more common R\&D tax credits used in other countries - and also to lesser extent in Belgium - which are dependent on turnover or profits. The amount exempted started at 50\% of wage withholding tax for YICs and collaborative projects and $25 \%$ for $\mathrm{PhD}$ and MA holders, but the rate was raised to $65 \%$ in 2008 and $75 \%$ from 2009 for all categories. The Belgian measure can be freely spent by firms on any activity, be it related to R\&D or not.

Table 1illustrates the evolution over time of the population of firms receiving tax credits, subsidies or the policy mix. We observe an abrupt increase in the uptake of tax credits in 2006 and 2007, as the measure opened to more categories of researchers, but also in 2009, when the percentage of exempted tax was raised to $75 \%$. This increase is also visible in the average tax credit per firm, which rises steadily before 2008 from 36 to 92 thousand Euros, then encountering a more abrupt rise for two years up to 217 thousand Euros, only to slightly drop in 2010 and 2011. This decline is mostly due to a larger number of users, as the total amount of foregone tax in the economy remained at similar levels in 2009-2011, at around 290 million Euros. Subsidies, on the other hand, show a steadier trend, mostly due to a more even 
policy environment over time. Subsidy users remain around or above 800 firms per year, with a drop in 2009 and 2010, possibly correlated with the downturn in world financial markets. Regarding the amount of subsidies received on average by firms, it started at almost four times the average tax credit, i.e. 133 thousand Euros. There is no clear trend though, as it raises and drops in an apparently disordered fashion up to 2011, when it surges by almost 80 thousand Euros to 259 thousand. The last panel displays firms combining tax credits and subsidies in the same year. As expected, the trend follows the lines of the singular policies, but we mostly see a steady increase in the number of firms and the average amount received. The average amount of the policy mix in 2005 was 870 thousand Euros, many times higher than the average tax credit and subsidy amounts combined. This is mostly due a few firms with very large R\&D departments, given that only 33 companies used the mix in that year. Moreover, the tax exemption in 2005 only applied to researchers hired on collaborative projects and stood at $50 \%$ of their wage withholding tax. The drop to almost half the average amount in 2006 follows from almost six times more users. There is also a large increase in 2009 of about 200 thousand Euros, on average, which is matched by an increase in the overall budget spent on firms combining the two by almost 65 million Euros.

Table 1. Population statistics by support type and period

\begin{tabular}{|r|r|r|r|r|r|r|r|r|r|}
\hline & \multicolumn{4}{|c|}{ Tax credits } & \multicolumn{3}{c|}{ Subsidies } & \multicolumn{3}{c|}{ Policy mix } \\
\hline Year & Users & Average & \multicolumn{1}{c|}{ Total } & Users & \multicolumn{1}{c|}{ Average } & \multicolumn{1}{c|}{ Total } & Users & Average & Total \\
\hline 2005 & 52 & 36 & 1.875 & 778 & 133 & 103.000 & 33 & 870 & 28.700 \\
\hline 2006 & 427 & 78 & 33.200 & 856 & 110 & 94.500 & 184 & 459 & 84.500 \\
\hline 2007 & 673 & 92 & 62.000 & 844 & 164 & 139.000 & 243 & 521 & 127.000 \\
\hline 2008 & 887 & 158 & 140.000 & 813 & 136 & 110.000 & 288 & 537 & 155.000 \\
\hline 2009 & 1242 & 217 & 270.000 & 703 & 141 & 98.900 & 299 & 735 & 220.000 \\
\hline 2010 & 1402 & 207 & 290.000 & 776 & 178 & 138.000 & 350 & 641 & 224.000 \\
\hline 2011 & 1459 & 198 & 289.000 & 885 & 259 & 229.000 & 394 & 788 & 311.000 \\
\hline
\end{tabular}

a) Numbers refer to the entire population of public support users.

b) Tax credits and subsidies categories include users of the policy mix.

c) Average and total columns in thousand Euros.

Figure 1 illustrates the evolution of the average amount received per company split into four mutually-exclusive groups or treatments: firms that receive only tax credits or only subsidies, and those receiving tax credits and subsidies part of a mix. It reveals that policy mix users receive on average larger amounts of both tax credits and grants compared to single policy users. The difference in average subsidies starts off high and diminishes in time, while tax credits follows the opposite trend - similar amounts for single policy and mix users, followed by a jump in 2008 , simultaneous with the raise in exemption rates. 


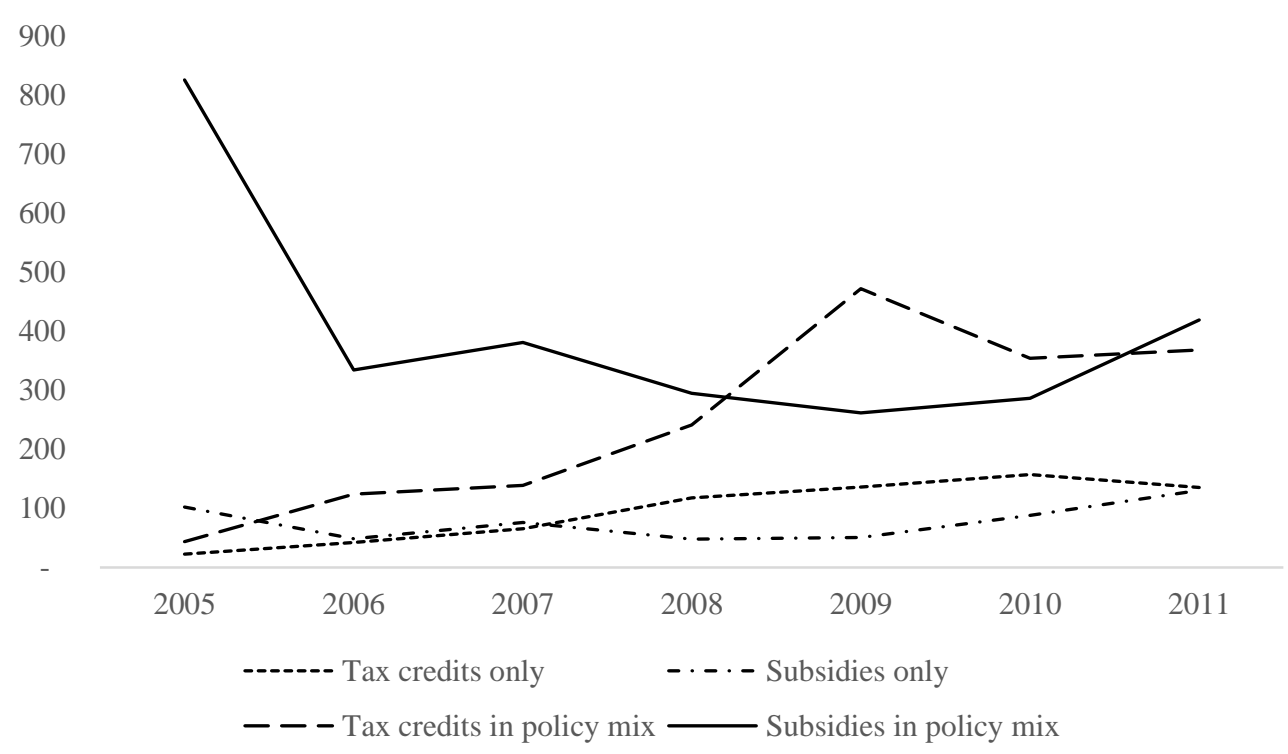

Figure 1. Evolution of average amount by policy measure Source: own calculations.

a) Categories are mutually-exclusive, thus numbers are not identical to, but based on Table 1.

b) Average amount received expressed in thousand Euros.

\subsection{Data}

I use a dataset comprising the 2008, 2010 and 2012 Business R\&D surveys on Belgian firms, coupled with employment, financial, fiscal and subsidy information from the Belgian Federal Public Service Finance. ${ }^{\text {iv }}$ Although non-R\&D data is a panel, the Business R\&D surveys have been applied to different samples of companies over the years, rendering the data usable in the form of repeated cross sections. ${ }^{\mathrm{v}}$

As I am interested in the effect of each policy on private $R \& D$ expenditure, the main dependent variables are extracted from survey questions where firms were asked the amounts spent on internal R\&D. However, rather than focusing solely on total R\&D expenditure, I also consider the allocation of R\&D budgets over different activities. Thus, I use survey questions regarding the share of R\&D expenditure by type of activity - basic research, applied research, and development - to test whether different types of public support for R\&D have (dis)similar, if any, effects on the allocationof R\&D budgets. The three different waves of the survey provide data on the outcome variables for the years 2007, 2009 and 2011.

Data on subsidies granted by the regional governments and on the federal tax credit for researchers is exhaustive and comprises the amounts received by the complete population of recipients. Firm characteristics - employment, location, financial data, etc. - are available as a panel, thus I am able to use lags of most independent and control variables in order to tackle possible simultaneity biases.

After checking the data for consistency, the sample for this analysis contains 2.650 observations on 1.809 firms. ${ }^{\text {vi }}$ 


\subsection{Method}

The main identification issue present in evaluation studies of public policy is the fact that funds are not randomly attributed to firms. In the case of subsidies, public authorities decide which projects to support from limited funds. On the other hand, firms using tax credits do not go through an evaluation process, but have their own considerations when deciding whether or not to demand tax breaks. Be it third-party selection or self-selection, the issue implies that firms using some type of public support for their R\&D differ ex ante from firms that do not use such measures, and the differences might be hidden to the researcher. Heckman et al. (1999) provide an overview of estimation strategies under the presence of selection bias, among which matching and instrumental variables (IV) estimators. The former is a non-parametric method that relies on the assumption that selection into programmes is based on observable characteristics of participants. The IV method requires that selection be tackled by exogenous instruments that only affect outcomes through their impact on the treatment variables. Trade-offs need to be made when choosing either method, as none is robust to all possible bias.

\subsubsection{Matching estimator}

To measure the effects each different policy has on R\&D budgets, I perform nearestneighbour matching using a flexible definition of treated and control groups on a pooled cross section of firms. For each outcome, I create four mutually-exclusive groups: users of tax credits, users of subsidies, users of both tax credits and subsidies ('policy mix'), and firms that do not receive any support. Based on the methodology developed by Gerfin and Lechner (2002), I consider grants, tax credits and the policy mix as heterogeneous treatments and analyse their effect on each outcome as the average treatment effect on the treated, $\alpha^{t, c}$, as

$$
E\left(\alpha^{t, c}\right)=E\left(Y^{t} \mid S=t\right)-E\left(Y^{c} \mid S=t\right)
$$

where $Y^{t}$ and $Y^{c}$ denote the outcomes for the treatment and the counterfactual states.

I then form pairwise comparisons of $t$ and $c$ states with the types of firms described above (policy mix users, tax credit users, subsidy users, non-users of public funds) as shown in Table 2.

Table 2Illustration of the different definitions of treated and control groups

\begin{tabular}{|c|c|c|c|c|}
\hline & \multicolumn{4}{|c|}{ Treatment } \\
\hline & & Policy mix & Tax credits & Subsidies \\
\hline \multirow{4}{*}{ } & No funding & Definition 1 & Definition 2 & Definition 3 \\
\hline & Policy mix & & Definition 4 & Definition 5 \\
\hline & Tax credits & Definition 6 & & Definition 7 \\
\hline & Subsidies & Definition 8 & Definition 9 & \\
\hline
\end{tabular}

a) Definition 1' analyses the effect on each outcome variable of the policy mix (tax credits and subsidies), versus the counterfactual of not having used any public funding. Analogously, 'Definition 7 analyses the additionality of subsidies compared to the counterfactual of using tax credits.

The method allows direct comparison of policies with each other, but also disentangling eachindividual effect that policies have compared to the counterfactual of not using any public funding. I use a two-step matching procedure. First, I estimate the propensity scores as 
the probability of being in each of the four groups. In order to do so, I employ a multinomial probit model on the four treatment groups - being a policy mix user, a tax credit user, a subsidy user, or not receiving any support - and condition on company characteristics that play a role in the selection into each of these policies. To make sure that a comparison between the estimated effects of each treatment definition is valid, I restrict the entire sample to common support so that all firms have a positive probability of participating in all four states. This translates to keeping only those observations with probability of being observed in state $t\left(P^{t}\right)$ larger than the highest minimum and smaller than the lowest maximum of all probabilities $P^{t}$ observed for each state $t=1 \ldots 4$.

In a second step, for each combination of states $t$ and $c$, for each firm in state $t$, a similar firm in state $c$ is found based on the smallest Mahalanobis distance calculated on the propensity scores $P^{t}$ and $P^{c}$. Furthermore, given that I use a pooled cross section, an exact match on the year in which the outcomes are measured is required. When a match is found, the firm in state $t$ is taken out of the sample, while the one in state $c$ is kept as a possible control for the remaining firms in state $t$ (matching with replacement). When all firms in state $t$ have been matched, the treatment effects are estimated using the matched firms in states $t$ and $c$.

\subsubsection{Instrumental variables estimator}

For matching estimators to be valid, all characteristics affecting selection into subsidy or tax credit programmes must be observed. In other words, potential outcome and participation in a programme must be independent given the observed set of characteristics - the conditional independence assumption (Rubin, 1977). As this assumption is rather strong and cannot be tested empirically, I also estimate the treatment effects by instrumental variables methods, which are more robust to selection on unobserved characteristics.

The main concern is that, although the dataset is quite extensive, some variables that have been previously used in similar studies and may affect selection are not available. The main unobserved factor in most studies is the intrinsic quality of the firm and of its R\&D projects. Authorities base their selection of grantees on comprehensive descriptions of the proposed projects, the past achievement of candidates and other characteristics that are not available in the current data base. Furthermore, matching estimators only provide a general view of the effects of policies on outcomes. Even though I try to solve this issue by matching on different categories of treatment, this solves the issue only partially. Dose-response methods based on a generalised propensity score have been employed to some effect in literature in order to assess whether treatment effects vary with treatment level (Hottenrott et al., 2014; Marino et al., 2016). Nevertheless, such models only allow comparisons between different levels of the same treatment, rather than between different treatments.

Instrumental variables estimators help dealing with unobserved heterogeneity among firms. They estimate parametrically the effect of the amount of each treatment received controlling for each other type of treatment. Should selection not be an issue - for example if firms were randomly attributed public funds for $\mathrm{R} \& \mathrm{D}$ - then regressing the outcome variables on the subsidy and tax credit amounts by ordinary least squares would provide unbiased estimates of the effects of each policy measure on private R\&D. However, in the presence of (self-) selection, the subsidy and tax credit amounts are endogenous and need to be instrumented. Valid instruments should be correlated with subsidy and tax credit amounts, but uncorrelated with any unobserved factors influencing outcome - R\&D spending, total and split by activity. A robust instrument would thus be the amount of subsidies and tax credits that each firm 
could potentially receive (Lichtenberg, 1987). I use two distinct features of subsidies and tax credits in Belgium to identify the endogenous variables.

First, subsidies are granted by regional governmental agencies with budgets that are fixed prior to the payment period. Thus, the overall subsidy budget for each agency is exogenous to firm characteristics. However, following Wallsten (2000), one cannot assume that the entire budget of an agency is potentially available to each firm. Therefore, I calculate the average amount of subsidies received by a firm per year, administrative region, industry defined by 4digit NACE codes, and size class - indicated by an SME dummy. I also calculate the number of firms receiving subsidies within these groups. These two instruments together capture the variation over time of the overall budgets of granting agencies, the variation of the budgets of different agencies, and also the availability of subsidies to different industries.

Second, tax credits differ from subsidies in that there is no fixed budget available to firms. Thus, in theory, the amount of tax credits can vary from zero to infinity. However, following work byNeicu et al. (2016), I rely on the existence of peer effects in the spread of new policy for R\&D. Analysing the same tax credit for Belgian firms, they show that firms have a higher propensity of using the measure if their peers - firms within the same industry and geographical proximity - use it too. By defining the average amount of tax credits per firm and the number of users by year, region, industry and size class, I construct an instrument that is correlated with each firm's amount of tax credits received, while exogenous to its $R \& D$ spending. ${ }^{\text {vii }}$

\subsection{Variables}

\subsubsection{Dependent variables}

In order to assess the effects of each policy on firms' R\&D activity, I first employ a standard dependent variable used in input additionality literature - the log of private R\&D expenditure ( $L N R \& D N E T$ ). I define private $\mathrm{R} \& \mathrm{D}$ spending as intra-mural $\mathrm{R} \& \mathrm{D}$ expenditure, net of any public support received. I select my sample to include only firms that have non-negative private $R \& D$ expenditure, and positive total $R \& D$. That is to say that I only analyse R\&Dactive firms. Although this might drive down some of the significance of the results, I consider it appropriate to exclude firms in periods when they do not report any R\&D activity. Further, I split total R\&D expenditure by type of activity: basic research, applied research, and development. Firms were asked in the Business R\&D Survey what percentage of their total internal R\&D expenses make up each category. I multiply each percentage with the total R\&D expenditure to create a variable that captures the overall volume of R\&D by activity (LN BASIC RES, LN APPLIED RES, LN DEVELOPMENT).

Lastly, I test the effects of policies on the percentage of development in total R\&D (DEVELOPMENT INT), and, by extrapolation, the percentage of total research as (1DEVELOPMENT INT). The difference between the last two sets of outcomes stands in that the former allow to examine input additionality that policies create in terms of increasing or decreasing the volume of basic, applied research or development activities of a firms, while the latter allows an analysis of the behavioural additionality induced by policies. In other words, one shows us if receiving public subsidies or tax credits has lead firms to increase their private expenditure in either of the three categories, while the other will indicate if firms have shifted funds from development to research as a result of using public support for R\&D. viii 


\subsubsection{Treatment variables}

The variables used to define treatment status for the matching estimators are binary variables indicating whether a firm has received a 'treatment' comprising only subsidies (SUBS), only tax credits $(T A X)$, both subsidies and tax credits $(M I X)$, or no support (NOSUP) during the years covered by each survey (i.e. 2007, 2009 and 2011). ${ }^{\text {ix }}$ This specification allows estimating the average effect of each treatment on the outcomes, irrespective of the amount of support received. Indeed, it assumes that, on average, the amounts are the same between the three treatments.

I then use the available data on the amount of tax credits and subsidies received by firms in the instrumental variables estimation. By taking the natural logarithm of these amounts, I can interpret the coefficients in terms of the effect of percentage increases in the independent variables on the dependent one. Because the IV model is parametric, I am able to model the impact of both the amount of subsidies (LN SUBS) and tax credits (LN TAX) received simultaneously. This allows establishing the marginal effect each policy has on the outcomes. In a second step, I define the total amounts for firms that use both policies $(L N M I X)$. This definition allows examining, similarly to the matching estimator, whether subsidies and tax credits show higher additionality when combined in a policy mix.

\subsubsection{Instrumental variables}

I instrument each endogenous variable by two exogenous instruments: the average of that variable by size class (SME or large firms) year, region and industry, and the number of firms with a non-zero value for the variable. Thus, I instrument $L N S U B S$ and $L N S U B S O N L Y$ with LNAVGSUBS and NRSUBS USERS, LNTAX and LN TAX ONLY with LNAVGTAX and NRTAX USERS, and LNMIX with LNAVGMIX and NRMIX USERS.

\subsubsection{Control variables}

The age and size of firms have been shown to capture experience effects in dealing with public support agencies. The logarithm of age ( $L N A G E)$ will capture such effects, as one expects older firms to rely on more past knowledge regarding the availability of public funding. Moreover, the variable should capture whether younger firms invest more in R\&D than established firms in the instrumental variables regressions. The size of a firm is usually found to affect the probability of receiving public support either by capturing scale effects on the opportunity cost of applying or the specific targeting by funding agencies of categories of firms (Blanes \& Busom, 2004; Neicu et al., 2016). Size effects might also play a role in determining a firm's R\&D budget and how it is split between research and development. I include the lagged number of employees in logarithm in the estimation to account for size effects $(L N E M P)$. Belgian regional authorities offer grants for small and medium enterprises, and I control for this by including an SME indicator $(S M E)$.

Capital-intensive firms have been found to have a higher probability of engaging in $R \& D$, and consequently, having higher chances of receiving public support (Blanes \& Busom, 2004). I include a measure of capital intensity as the ratio of fixed assets to employees in logarithm (LNCAPINT). Moreover, I control for a firm's financial health by its current ratio (CURR), defined as the ratio of current to total assets. Whether a company has enough financial resources can have an influence on its incentive to request public support, but also invest more on R\&D activities. Czarnitzki et al. (2011) have found that working capital has a positive impact on total R\&D spending, but also a larger impact on $R$ than on $D$.

To capture sectorial patterns related to $R \& D$ activity and the possible targeting of specific industries by policy makers, I define high- and low-tech service and manufacturing industries, 
and include binary variables for each in the estimation. Given that subsidies in Belgium are managed by the regional governments, while tax credits are managed by the federal government, I include binary indicators for firms located in Flanders and in Wallonia, keeping Brussels as baseline. Year dummies are included to account for the different waves of the business R\&D survey covered by the sample.

I also include in the parametric estimation of $R \& D$ expenditure, total and per activity, the financial leverage ( $L E V E R$ ), denoting a firm's debt to equity ratio in order to capture firms' access to the credit market. Czarnitzki et al. (2011) find that this variable has a significant impact on R\&D activity, as firms with higher debt rates perform less research, while the impact on development is insignificant.

The control variables - except for age, industry and region dummies - are measured in the year prior to the measurement of outcomes. This ensures, to the extent possible given the data, maximum sample size and addresses possible simultaneity concerns.

\subsubsection{Descriptive statistics}

Table 3 displays mean values and standard deviations for the control and outcome variables before matching. They are aggregated by treatment, i.e. by type of support received. In the pooled cross sections, 1,363 firms did not receive any public funding for $\mathrm{R} \& \mathrm{D}, 644$ only received tax credits, 237 received only subsidies, and 406 used a mix of both.

Table 3. Summary statistics of sample variables

\begin{tabular}{|c|c|c|c|c|c|c|c|c|}
\hline & \multicolumn{2}{|c|}{$\begin{array}{c}\text { No support } \\
(\mathrm{N}=1363)\end{array}$} & \multicolumn{2}{|c|}{$\begin{array}{c}\text { Tax credits only } \\
(\mathrm{N}=644)\end{array}$} & \multicolumn{2}{|c|}{$\begin{array}{c}\text { Subsidies only } \\
(\mathbf{N}=237)\end{array}$} & \multicolumn{2}{|c|}{$\begin{array}{l}\text { Policy mix } \\
(\mathrm{N}=406)\end{array}$} \\
\hline & Mean & s.d. & Mean & s.d. & Mean & s.d. & Mean & s.d. \\
\hline Tax credits* & 0.00 & 0.00 & 188 & 883 & 0.00 & 0.00 & 482 & 1.444 \\
\hline Subsidy* & 0.00 & 0.00 & 0.00 & 0.00 & 140 & 550 & 466 & 1.219 \\
\hline Policy mix* & 0.00 & 0.00 & 0.00 & 0.00 & 0.00 & 0.00 & 948 & 2.458 \\
\hline R\&D exp.* & 531 & 2.521 & 4.341 & 30.000 & 1.537 & 6.821 & 9.151 & 34.500 \\
\hline Basic R exp.* & 22 & 172 & 196 & 1.825 & 130 & 779 & 1.044 & 7.639 \\
\hline Applied R exp.* & 224 & 824 & 1.213 & 3.332 & 805 & 2.711 & 3.971 & 13.400 \\
\hline Develop. exp.* & 285 & 2.331 & 3.119 & 29.800 & 742 & 6.000 & 5.083 & 23.300 \\
\hline \% basic R. & 5.82 & 15.54 & 5.50 & 13.07 & 7.72 & 15.42 & 8.22 & 14.39 \\
\hline$\%$ applied $\mathrm{R}$. & 50.73 & 37.02 & 53.27 & 33.73 & 57.66 & 33.72 & 52.61 & 30.94 \\
\hline \% develop. & 43.45 & 37.40 & 41.23 & 33.80 & 34.62 & 32.96 & 39.17 & 31.67 \\
\hline Age & 25.16 & 17.63 & 24.13 & 18.10 & 22.75 & 17.25 & 26.29 & 24.78 \\
\hline Employees & 86.58 & 232.97 & 197.43 & 512.41 & 99.96 & 305.35 & 349.32 & 640.16 \\
\hline SME & 0.92 & 0.27 & 0.81 & 0.39 & 0.92 & 0.28 & 0.69 & 0.46 \\
\hline Leverage & 3.87 & 21.22 & 148.14 & 2757.19 & 38.22 & 532.63 & 3.12 & 8.58 \\
\hline Current ratio & 2.22 & 3.01 & 2.70 & 5.11 & 2.21 & 2.47 & 2.98 & 4.64 \\
\hline Capital intens. ${ }^{*}$ & 187 & 1.630 & 283 & 1.982 & 157 & 795 & 184 & 418 \\
\hline High-tech man. & 0.19 & 0.39 & 0.24 & 0.43 & 0.29 & 0.45 & 0.38 & 0.49 \\
\hline High-tech serv. & 0.25 & 0.43 & 0.30 & 0.46 & 0.31 & 0.46 & 0.32 & 0.47 \\
\hline Low-tech man. & 0.33 & 0.47 & 0.26 & 0.44 & 0.21 & 0.41 & 0.18 & 0.39 \\
\hline Low-tech serv. & 0.17 & 0.38 & 0.15 & 0.36 & 0.16 & 0.36 & 0.09 & 0.28 \\
\hline Brussels & 0.07 & 0.26 & 0.08 & 0.27 & 0.07 & 0.26 & 0.09 & 0.28 \\
\hline Flanders & 0.68 & 0.47 & 0.65 & 0.48 & 0.84 & 0.37 & 0.83 & 0.37 \\
\hline Wallonia & 0.24 & 0.43 & 0.27 & 0.45 & 0.09 & 0.29 & 0.08 & 0.27 \\
\hline
\end{tabular}

* Amounts expressed in thousand Euros.

The first three rows paint a similar picture to the one seen in Table 1 and 
Figure 1. As in the population statistics, policy mix users receive almost three times the amounts of subsidies and tax credits than the users of single measures. They receive the two measures in almost equal quantities - 482,000 Euros in tax credits and 466,000 Euros in grants.

We also observe that users of public support have higher net R\&D expenditure than nonusers. Subsidy recipients spend three times more, tax credit users up to eight times more, while firms receiving the policy mix spend on average seventeen times more on R\&D from private sources. All treatment groups show higher average spending on basic and applied research, but also on development.

Firms that use the policy mix are older and larger than the other categories. On the other hand, SMEs are better represented in the subsidy-only group, which was expected due to the specific grants for these firms offered by all regional authorities. However, only $69 \%$ of policy mix users are SMEs, significantly lower than the other groups. Leverage shows the debt to equity ratio of firms, and we can see that single-policy users have higher leverage ratios, although the numbers are driven by a few outliers.

The industry split shows that most firms receiving support are active in high-tech sectors, but policy mix users are more concentrated in high-tech manufacturing. Finally, we note an overrepresentation of firms from Flanders in the sample, which can either be a missing data issue or an effect of the region harbouring relatively more $\mathrm{R} \& \mathrm{D}$ active firms.

These statistics already show some interesting facts about the distribution of firms into each treatment group by their characteristics, and their relative clustering is in line with the different policies implemented by funding agencies (e.g. subsidies being targeted at SMEs).

\section{RESULTS}

\subsection{Estimated propensities to receive treatment}

In a first step, I estimate a multinomial probit model on the four (mutually exclusive) categories denoting the receipt of each treatment (only tax credits, only subsidies, and a policy mix) or not receiving any support. The sample comprises 2,650 firm-entries, of which around half $(1,363)$ have not received any treatment. ${ }^{\mathrm{x}}$

The results in

Table 6in Appendix show that larger and younger firms in high-tech industries have a higher probability of receiving tax credits or using the policy mix. Somewhat surprising, being an SME translates into a lower propensity of accessing R\&D subsidies, although regional governments have a pro-SME policy in Belgium (Hottenrottet al., 2014). Instead, high-tech firms from Brussels and Flanders have a higher propensity of receiving subsidies from the respective regional governments. Furthermore, the financial resources of a firm, measured by the current ratio, have a positive impact on their propensity to receive the policy mix.

Following these results, I use the estimated propensity scores and apply a common support restriction that drops 407 companies with estimated probabilities of being in treatment group $t$ larger than the lowest maximum probability over the four treatment groups $t$, or smaller than the highest minimum probability over the same groups. Subsequently, for each combination of treatment $t$ and control group $c$, each treated firm in group $t$ (where $t$ is based on each definition of treatment - policy mix, only tax credits, only subsidies) is matched to the most 
similar firm in group $c$ (comprising the three treatments and the firms not using any policy), based on the Mahalanobis distance between the two firms' propensities to be in groups $t$ and $c$ $\left(P^{t}\right.$ and $\left.P^{c}\right)$. Furthermore, exact matches are required on the year in which the characteristics are measured.

\subsubsection{Average treatment effects on private $R \& D$ expenditure}

The estimations of the average treatment effect on the treated (ATT)for each policy on private $\mathrm{R} \& \mathrm{D}$ expenditure are presented in Table 4 . Because the group of firms that only received subsidies is half the size of tax credits and policy mix user groups, the procedure does not result in proper balance between treatment and counterfactual groups when the latter comprises subsidy users, even though the matching is done with replacement. The Wald chisquare statistics for the tax credits-subsidies and policy mix-subsidies are significant at $1 \%$ level, so the ATT's are not reported in the table below as they violate the method's main assumption - i.e. that the only difference between treated and non-treated firms is treatment status, conditional on covariates. ${ }^{\text {xi }}$ However, when treatment are subsidies, the control groups are larger than the treatment group, thus ATT's are calculated on balanced groups. Throughout the paper I only report ATT's on balanced groups post-matching, i.e. for which the matching procedure produces reliable results.

Table 4. ATT on log-levels of overall private R\&D expenditure, and on the share of basic and applied research, and of development

\begin{tabular}{|c|c|c|c|c|c|}
\hline & \multicolumn{3}{|c|}{ Actual state } & \multirow{2}{*}{ Outcome } \\
\hline & & Policy mix & Tax credits & Subsidies & \\
\hline \multirow{12}{*}{ 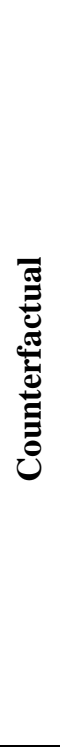 } & \multirow{4}{*}{ No support } & $1.45^{* * *}$ & $0.96^{* * *}$ & 0.02 & Private R\&D expenditure \\
\hline & & $3.15^{* * *}$ & $1.03^{* * *}$ & $1.52^{* * *}$ & Basic research \\
\hline & & $3.48^{* * *}$ & $1.90^{* * *}$ & $1.20^{* * *}$ & Applied research \\
\hline & & $1.51^{* * *}$ & $1.04^{* * *}$ & -0.55 & Development \\
\hline & \multirow{4}{*}{ Policy mix } & & $-0.47^{* * *}$ & $-0.89^{* * *}$ & Private $R \& D$ expenditure \\
\hline & & & $-1.90^{* * *}$ & -0.38 & Basic research \\
\hline & & & $-1.43^{* * *}$ & $-1.19^{* * *}$ & Applied research \\
\hline & & & -0.55 & $-1.68^{* * *}$ & Development \\
\hline & \multirow{4}{*}{ Tax credits } & $0.40^{* * *}$ & & $-0.80^{* * *}$ & Private R\&D expenditure \\
\hline & & $1.49^{* * *}$ & & 0.72 & Basic research \\
\hline & & $1.35^{* * *}$ & & -0.20 & Applied research \\
\hline & & 0.65 & & $-1.55^{* *}$ & Development \\
\hline
\end{tabular}

a) ${ }^{* * *},{ }^{* *}$, and ${ }^{*}$ indicate significance levels of $1 \%, 5 \%$ and $10 \%$, respectively.

b) Tax credits and subsidies groups refer to use of each policy as a single measure.

c) The first row displays additionality of each treatment compared to the counterfactual of not receiving support. Each column benchmarks treatments with each other.

The "No support" rows in the table show the effect of each policy compared to the counterfactual of not having received any support. The results indicate that using tax credits alone or combined with subsidies has a positive effect on private $R \& D$, compared to the counterfactual of not having received any support. On average, policy mix users spend 4.26 times $^{\mathrm{xii}}$ more on R\&D from their own funds, while tax credits users spend 2.61 times more than firms that do not receive any support. However, the results also show that subsidy users 
do not spend significantly different amounts of own funds on R\&D than what they would have spent without having received any support.

The comparison between different policies reveals that the policy mix outperforms both tax credits (by $49 \%$ extra R\&D expenditure) and subsidies (2.44 times more) that are used separately. ${ }^{\text {xii }}$ Moreover, subsidy recipients spend 2.23 times less of their own funds on R\&D than they would have spent had they received tax credits instead. Overall, it is the combination of subsidies and tax credits that induces the larger effect.

\subsubsection{Average treatment effects on basic, applied research and development}

I now focusthe analysis on the effect of the policies on different components of R\&D. The results are also presented in Table 4.

Note that due to the nature of the Business R\&D survey, one can only observe firms' total expenditure on each R\&D component. Thus, it is possible that, for example, an increase in basic research spending is prompted by a specific subsidy that a firm receives, and the increase would only mirror the amount of the subsidy without spurring additional spending of the firm's own funds. If the firm had spent less resources on basic research prior to receiving the subsidy, this suggests that the subsidy itself has induced a behavioural change in the user. The difference between input and behavioural additionality is relevant up to the point of policy makers' interest in disentangling all the possible effects a policy may have on R\&D behaviour.

All policies have a positive effect on the amount that firms spend on basic research activities. On average, a recipient of the policy mix spends 23.34 times more on basic research than what they would have spent without receiving support. Tax credits users spend 2.80 times more on basic research, while subsidy users spend4.57 times more. The policy mix also outperforms tax credits by a factor of 4.44 , but the difference between subsidies and the policy mix is not significant. This might imply that subsidies drive most of the effect, or that the volume of support may play a role, such that when faced with greater volumes of financial slack, firms are more inclined to use it on farther-from-the-market research activities.

Subsequently, I analyse the effect of each policy on applied research. The results show that all types of public support have a positive effect on this outcome, compared to the counterfactual of not receiving public support for R\&D.On average, the policy mix increases spending on applied research activities 32.46 times, while tax credits only 6.69 times and subsidies by a factor of 3.32. The difference between tax credits and subsidies, on the one hand, and the combination of the two, on the other hand, is significant at $1 \%$. Indeed, policy mix users spend 3.86 times more on applied research than tax credit users and 3.29 times more than subsidy users, while the difference between the latter two groups is not significant, albeit negative in favour of tax credits. These results suggest that the effect of policy on applied research spending is purely based on the amount received, irrespective of the type of policy. ${ }^{\text {xiv }}$

Lastly, the policies' effects on development spending show that users of the policy mix spend 4.53 times more on their development activities compared to firms receiving no support, while those using tax credits spend2.83 times more. On the other hand, subsidies do not show any significant effect, and firms using subsidies spend, on average, significantly less on development than policy mix or tax credit users. This suggests that subsidies crowd-out private spending on development, i.e. on projects that that are closer to the market. 
The combined results show that firms using tax credits or the policy mix increase spending on basic and applied research, and, to a smaller extent, on development. The more interesting conclusion might be that the policy mix also brings behavioural changes in firms, leading them to focus more resources on research activities compared to development. ${ }^{\mathrm{xv}}$ Subsidies, on the other hand, show an even stronger behavioural effect, as they do not increase spending on development, but they cause a shift in funds from development towards research. However, as I mentioned previously, firms can receive subsidies either for research or development projects. This is the case of the IWT, the Flemish funding agency, which grants higher percentages of project costs for research than for development projects. In 2007, research subsidies amounted to around $35 \%$ of total subsidies granted by the IWT, while development grants were over $50 \%$. In 2009, the difference between the two contracted to under $10 \%$ (Hottenrott et al., 2014). Given that $83 \%$ of subsidy-only recipients in my sample are Flemish firms, the effects could well be driven by this specific policy design. Hottenrott et al. (2014) do find positive and significant direct effects of both types of subsidies on research and development, but they also find cross-effects from research subsidies to development and vice-versa. However, they find larger effects on research for the period between 2005 and 2009, which corresponds to a policy shift towards targeted support. As I analyse three periods - 2007, 2009 and 2011, it could be that the driver behind my results is an increase in research grants relative to development grants post-2009. Combined with a higher direct effect of research grants, these characteristics could explain the finding that on average, subsidies increase spending on research but not on development.

\subsection{Instrumental variables estimations}

As the matching procedure only accounts for selection of firms into treatments based on observed characteristics, it may provide biased estimates if this assumption does not hold. One can think of several ways this could happen, as the researcher rarely has extensive data on (self-) selection. For example, firms might have a better chance of receiving subsidies if they have used them to good effect in the past, whatever 'good effect' might mean to the policy maker. Similarly, a firm's decision to request tax credits might be in the hands of its overseas headquarters. Moreover, a parametrisation of some sort is needed to obtain better insight into how the amounts received affect firms' budgetary choices.

In order to do so I introduce the instruments described in section 0 , but also a new independent variable ( $L E V E R$ ) measuring a firm's debt to equity ratio - leverage - in order to capture firms' access to the credit market. Czarnitzki et al. (2011) find that this variable has a significant impact on R\&D activity, as firms with higher debt rates perform less research, while the impact on development is insignificant.

I estimate the effect of the level of tax credits and subsidies, used separately and combined, on the private R\&D spending and on the basic and applied research and development spending of firms by a series of instrumental variables regressions estimated through two-stage least squares (2SLS).

I test the instruments' relevance by Anderson's canonical correlation statistic and their overidentification with Hansen's J test. The former confirms that the instruments are relevant in explaining the endogenous repressors in all equations, while the latter's insignificance confirms that the instruments are exogenous in the main equations. However, if I would instrument policy mix use with the excluded variables used to instrument tax credits and subsidies, the over-identification would fail in the policy mix equations. This is a direct consequence of the fact that I would exclude part of the effect of tax credits and subsidies 
from the estimation, passing them to the error term. This in turn becomes correlated with the excluded instruments used for the endogenous variable of the policy mix. To mitigate this issue, I construct instruments for the policy mix variable similar to those used for tax credits and subsidies: the average amount of policy mix received and the number of firms receiving it per year, industry and size category. The two instruments are valid in that they are correlated with the amount of policy mix received and uncorrelated with the error term of the main equation. ${ }^{\text {xvi }}$ The results of the first-stage estimations on the amount of each treatment received is presented in Table 7 in Appendix.

The results are presented in Table 5, where the first two rows show the overall average effects of tax credits and subsidies, and the following three rows disentangle their impact when used as single measures from that of the policy mix.

Table 5. Instrumental variables (2SLS) estimations of policy effects

\begin{tabular}{|c|c|c|c|c|c|c|c|c|}
\hline & \multicolumn{2}{|c|}{ LN R\&D NET } & \multicolumn{2}{|c|}{ LN BASIC RES } & \multicolumn{2}{|c|}{ LN APPLIED RES } & \multicolumn{2}{|c|}{ LN DEVELOPMENT } \\
\hline & $a$ & $b$ & $c$ & $d$ & $e$ & $f$ & $g$ & $h$ \\
\hline LN TAX & $\begin{array}{c}0.15^{* * *} \\
(0.02)\end{array}$ & & $\begin{array}{c}0.18^{* * * *} \\
(0.06)\end{array}$ & & $\begin{array}{c}0.23^{* * *} \\
(0.05)\end{array}$ & & $\begin{array}{c}0.20^{* * *} \\
(0.06)\end{array}$ & \\
\hline LN SUBS & $\begin{array}{l}0.04^{* *} \\
(0.02)\end{array}$ & & $\begin{array}{l}0.15^{* *} \\
(0.06)\end{array}$ & & $\begin{array}{c}0.14^{* * *} \\
(0.05)\end{array}$ & & $\begin{array}{r}0.05 \\
(0.06)\end{array}$ & \\
\hline LN MIX & & $\begin{array}{c}0.18^{* * *} \\
(0.02)\end{array}$ & & $\begin{array}{c}0.32^{* * *} \\
(0.07)\end{array}$ & & $\begin{array}{c}0.36^{* * *} \\
(0.05)\end{array}$ & & $\begin{array}{c}0.22^{* * * *} \\
(0.06)\end{array}$ \\
\hline LN TAX ONLY & & $\begin{array}{c}0.14^{* * *} \\
(0.02)\end{array}$ & & $\begin{array}{l}0.19^{* *} \\
(0.07)\end{array}$ & & $\begin{array}{c}0.20^{* * * *} \\
(0.07)\end{array}$ & & $\begin{array}{l}0.17^{* * *} \\
(0.08)\end{array}$ \\
\hline LN SUBS ONLY & & $\begin{array}{r}0.01 \\
(0.04)\end{array}$ & & $\begin{array}{r}0.18 \\
(0.13)\end{array}$ & & $\begin{array}{r}0.06 \\
(0.12)\end{array}$ & & $\begin{array}{r}0.00 \\
(0.13)\end{array}$ \\
\hline LN AGE & $\begin{array}{c}-0.12^{* *} \\
(0.05)\end{array}$ & $\begin{array}{c}-0.12^{* *} \\
(0.05)\end{array}$ & $\begin{array}{r}0.15 \\
(0.20)\end{array}$ & $\begin{array}{r}0.17 \\
(0.20)\end{array}$ & $\begin{array}{r}-0.00 \\
(0.14)\end{array}$ & $\begin{array}{r}0.01 \\
(0.14)\end{array}$ & $\begin{array}{r}0.05 \\
(0.20)\end{array}$ & $\begin{array}{r}0.03 \\
(0.20)\end{array}$ \\
\hline LN EMP & $\begin{array}{c}0.63^{* * *} \\
(0.04)\end{array}$ & $\begin{array}{c}0.63^{* * *} \\
(0.04)\end{array}$ & $\begin{array}{r}0.18 \\
(0.13) \\
\end{array}$ & $\begin{array}{r}0.17 \\
(0.12) \\
\end{array}$ & $\begin{array}{c}0.44^{* * * *} \\
(0.11)\end{array}$ & $\begin{array}{c}0.44^{* * *} \\
(0.10)\end{array}$ & $\begin{array}{c}0.56^{* * *} \\
(0.13)\end{array}$ & $\begin{array}{c}0.58^{* * *} \\
(0.13)\end{array}$ \\
\hline SME & $\begin{array}{c}-0.04 \\
(0.14) \\
\end{array}$ & $\begin{array}{r}-0.04 \\
(0.14) \\
\end{array}$ & $\begin{array}{r}-0.69 \\
(0.53) \\
\end{array}$ & $\begin{array}{r}-0.67 \\
(0.53) \\
\end{array}$ & $\begin{array}{r}0.17 \\
(0.37) \\
\end{array}$ & $\begin{array}{r}0.18 \\
(0.37) \\
\end{array}$ & $\begin{array}{r}-0.56 \\
(0.47) \\
\end{array}$ & $\begin{array}{r}-0.60 \\
(0.47) \\
\end{array}$ \\
\hline LEVER & $\begin{array}{c}0.00^{* * * *} \\
(0.00)\end{array}$ & $\begin{array}{c}0.00^{* * * *} \\
(0.00)\end{array}$ & $\begin{array}{r}0.00 \\
(0.00) \\
\end{array}$ & $\begin{array}{r}0.00 \\
(0.00) \\
\end{array}$ & $\begin{array}{c}0.00^{* * * *} \\
(0.00)\end{array}$ & $\begin{array}{c}0.00^{* * * *} \\
(0.00)\end{array}$ & $\begin{array}{c}0.00^{* * * *} \\
(0.00)\end{array}$ & $\begin{array}{c}0.00^{* * * *} \\
(0.00)\end{array}$ \\
\hline CURR & $\begin{array}{r}0.00 \\
(0.01) \\
\end{array}$ & $\begin{array}{r}0.00 \\
(0.01) \\
\end{array}$ & $\begin{array}{c}-0.01 \\
(0.01) \\
\end{array}$ & $\begin{array}{c}-0.01 \\
(0.01) \\
\end{array}$ & $\begin{array}{r}0.01 \\
(0.01) \\
\end{array}$ & $\begin{array}{r}0.01 \\
(0.01) \\
\end{array}$ & $\begin{array}{r}-0.00 \\
(0.01) \\
\end{array}$ & $\begin{array}{r}-0.00 \\
(0.01) \\
\end{array}$ \\
\hline LN CAPINT & $\begin{array}{c}0.11^{* * * *} \\
(0.02)\end{array}$ & $\begin{array}{c}0.11^{* * *} \\
(0.02)\end{array}$ & $\begin{array}{l}0.17^{* *} \\
(0.08)\end{array}$ & $\begin{array}{l}0.16^{* *} \\
(0.08)\end{array}$ & $\begin{array}{r}0.01 \\
(0.07) \\
\end{array}$ & $\begin{array}{r}0.01 \\
(0.07) \\
\end{array}$ & $\begin{array}{c}0.25^{* * * *} \\
(0.08)\end{array}$ & $\begin{array}{c}0.26^{* * * *} \\
(0.08)\end{array}$ \\
\hline HITECH M & $\begin{array}{l}0.37^{* *} \\
(0.15)\end{array}$ & $\begin{array}{l}0.38^{* * *} \\
(0.16)\end{array}$ & $\begin{array}{r}-0.77 \\
(0.55)\end{array}$ & $\begin{array}{r}-0.81 \\
(0.56) \\
\end{array}$ & $\begin{array}{c}0.82^{*} \\
(0.48)\end{array}$ & $\begin{array}{c}0.85^{*} \\
(0.49)\end{array}$ & $\begin{array}{c}-0.12 \\
(0.48)\end{array}$ & $\begin{array}{r}-0.05 \\
(0.49) \\
\end{array}$ \\
\hline HITECH S & $\begin{array}{c}0.85^{* * *} \\
(0.16)\end{array}$ & $\begin{array}{c}0.87^{* * * *} \\
(0.17)\end{array}$ & $\begin{array}{r}-0.68 \\
(0.57) \\
\end{array}$ & $\begin{array}{r}-0.71 \\
(0.57)\end{array}$ & $\begin{array}{l}1.04^{* * *} \\
(0.50)\end{array}$ & $\begin{array}{l}1.08^{* *} \\
(0.51)\end{array}$ & $\begin{array}{r}-0.15 \\
(0.51) \\
\end{array}$ & $\begin{array}{r}-0.08 \\
(0.51) \\
\end{array}$ \\
\hline LOWTECH M & $\begin{array}{r}-0.19 \\
(0.15) \\
\end{array}$ & $\begin{array}{r}-0.18 \\
(0.15)\end{array}$ & $\begin{array}{r}-0.44 \\
(0.52) \\
\end{array}$ & $\begin{array}{r}-0.43 \\
(0.52) \\
\end{array}$ & $\begin{array}{r}0.55 \\
(0.45) \\
\end{array}$ & $\begin{array}{r}0.56 \\
(0.46) \\
\end{array}$ & $\begin{array}{r}-0.15 \\
(0.44) \\
\end{array}$ & $\begin{array}{r}-0.14 \\
(0.43) \\
\end{array}$ \\
\hline LOWTECH S & $\begin{array}{l}0.33^{* *} \\
(0.16)\end{array}$ & $\begin{array}{l}0.35^{* *} \\
(0.16) \\
\end{array}$ & $\begin{array}{r}-0.07 \\
(0.56)\end{array}$ & $\begin{array}{c}-0.08 \\
(0.56)\end{array}$ & $\begin{array}{r}-0.20 \\
(0.50) \\
\end{array}$ & $\begin{array}{r}-0.15 \\
(0.51) \\
\end{array}$ & $\begin{array}{r}0.31 \\
(0.48) \\
\end{array}$ & $\begin{array}{r}0.35 \\
(0.48) \\
\end{array}$ \\
\hline FLANDERS & $\begin{array}{c}-0.34^{* *} \\
(0.13) \\
\end{array}$ & $\begin{array}{c}-0.34^{* * *} \\
(0.13)\end{array}$ & $\begin{array}{l}1.13^{* *} \\
(0.50)\end{array}$ & $\begin{array}{l}1.12^{* *} \\
(0.50)\end{array}$ & $\begin{array}{r}0.28 \\
(0.42) \\
\end{array}$ & $\begin{array}{r}0.27 \\
(0.43) \\
\end{array}$ & $\begin{array}{r}0.47 \\
(0.48) \\
\end{array}$ & $\begin{array}{r}0.48 \\
(0.48) \\
\end{array}$ \\
\hline WALLONIA & $\begin{array}{r}-0.19 \\
(0.15) \\
\end{array}$ & $\begin{array}{r}-0.19 \\
(0.15)\end{array}$ & $\begin{array}{r}-0.06 \\
(0.52) \\
\end{array}$ & $\begin{array}{r}-0.05 \\
(0.52) \\
\end{array}$ & $\begin{array}{r}-0.43 \\
(0.48) \\
\end{array}$ & $\begin{array}{r}-0.44 \\
(0.49) \\
\end{array}$ & $\begin{array}{l}1.22^{* *} \\
(0.54)\end{array}$ & $\begin{array}{l}1.20^{* * *} \\
(0.53)\end{array}$ \\
\hline$N$ & 2650 & 2650 & 2650 & 2650 & 2650 & 2650 & 2650 & 2650 \\
\hline$N$ firms & 1809 & 1809 & 1809 & 1809 & 1809 & 1809 & 1809 & 1809 \\
\hline
\end{tabular}




\begin{tabular}{|l|r|r|r|r|r|r|r|r|}
\hline & \multicolumn{2}{|c|}{ LN R\&D NET } & \multicolumn{2}{c|}{ LN BASIC RES } & \multicolumn{2}{c|}{ LN APPLIED RES } & \multicolumn{2}{c|}{ LN DEVELOPMENT } \\
\hline Hansen $J$ & 0.56 & 0.55 & 0.62 & 1.23 & 1.77 & 1.57 & 0.98 & 4.92 \\
\hline Hansen $J(d f)$ & 2 & 3 & 2 & 3 & 2 & 3 & 2 & 3 \\
\hline Anderson $u$-id & 238.10 & 108.40 & 238.10 & 108.40 & 238.10 & 108.40 & 238.10 & 108.40 \\
\hline Anderson $u$ - $i d(d f)$ & 3 & 4 & 3 & 4 & 3 & 4 & 3 & 4 \\
\hline
\end{tabular}

a) $* * *, * *$, and $*$ indicate significance levels of $1 \%, 5 \%$ and $10 \%$, respectively.

b) Robust standard errors clustered by firm.

c) Intercept term and year dummies included but not shown in table.

d) All Hansen's J over-identification tests insignificant at $10 \%$ level.

e) All Anderson under-identification tests significant at $1 \%$ level.

f) Base category for industry indicators comprises firms that do not fit in high- or low-tech groups. Base categories for region is Brussels.

g) Instruments include the number of users of each policy and average amount received by 4-digit NACE industries, year and size group. Details of first-stage regressions are provided in Table 7 in Appendix.

\subsubsection{Additionality on private $R \& D$ expenditure}

Both policies have a positive and significant effect on firms' private R\&D expenditure (first column), while tax credits also show a significantly larger coefficient than subsidies. As the variables are measured in natural logarithms, the interpretation is the following. Increasing the amount of tax credits by $10 \%$ would increase private R\&D spending by $1.5 \%$, while the same increase in subsidies only brings a $0.4 \%$ increase in spending. However, the effects are averaged over all firms that receive each type of support. To estimate whether they have a different impact when used as single policies, I estimate the equation by separating the amounts received as a single treatment from the amount received in a policy mix. The second column reveals that subsidies do not significantly increase private R\&D spending if they are used alone, whereas tax credits add an extra $1.4 \%$ for each $10 \%$ increase in their volume if used alone. Finally, increasing the amount of the policy mix by $10 \%$ causes firms to raise their private spending by $1.8 \%$.

The results indicate that subsidies increase private $R \& D$ spending only if they are used together with tax credits, which I interpret as evidence of complementarity between the two measures. Haegeland and Møen (2007b) also found evidence of complementarity in Norway, although Dumont (2017) provided some indication that Belgian subsidies and tax credits are substitutes. However, the latter finding can be the effect of selection bias that is unaccounted for.

Other firm characteristics that influence the amount spent on R\&D include age, size, debt, capital intensity and industry affiliation, but also geographical location. Younger and larger firms spend more on R\&D net of public support, as do firms with higher debt-to-equity ratios and capital intensity values. Similarly, companies in high-tech industries record higher amounts spent on R\&D, but also - surprisingly - firms in low-tech service sectors.

\subsubsection{Additionality on components of $R \& D$}

Both types of support show positive effects on basic and applied research spending. Increasing tax credits by $10 \%$ boosts basic and applied research expenditure by $1.8 \%$ and $2.3 \%$ respectively, while the same increase in subsidies raises them by $1.5 \%$ and $1.4 \%$ respectively. The average effect of subsidies seems to be driven again by complementarity with tax credits, as firms that only receive grants do not significantly increase their research expenditure. Tax credits do 'work alone', too, but their effect is smaller than that of the policy mix, which increases basic and applied spending by $3.2 \%$ and $3.6 \%$ respectively for a $10 \%$ raise in the amount received. Tax credits and the policy mix also show positive effects on 
development spending at a ratio of 1-to-5 in percentages. On the other hand, subsidies do not seem to affect this category in either setting.

Finally, I find that firm size and leverage have a positive and significant effect on applied research and development spending, although the size of the coefficient of debt-to-equity ratio is of the magnitude $10^{-4}$. Capital-intensive firms spend more on basic research and development, while those active in high-tech sectors record higher spending on applied research. ${ }^{\text {xvii }}$

Generally, the instrumental variables estimators produce similar results to the non-parametric matching method. However, some differences do exist - such as a loss of significance of the effect of subsidies on basic and applied research spending, when they are used as a single policy. This result can have two causes. First, it can be inherent to applying a parametric function to firms' expenditure on research, resulting in a loss of efficacy. Alternatively, it points to a possible violation of the CIA assumption of the matching estimator, which can bias the average treatment effect. By performing both parametric and non-parametric analyses, I mitigate, to the extent possible, the known issues that are integral to each method and provide robust comparisons of the effects of direct and indirect support for R\&D.

\section{CONCLUSIONS}

This paper contributes to the empirical evidence on the effects of R\&D subsidies and tax credits, while providing a much needed multiple-treatment analysis of a policy mix. Using a rich dataset of R\&D-active Belgian firms, I perform multiple matching and instrumental variable estimations to trace how using tax credits and grants allows companies to change how they manage R\&D budgets.

First, I cannot exclude crowding-out of private R\&D spending by subsidies, if they are used alone. I find robust evidence that firms that only receive grants do not spend more of their own funds than what they would have spent without support. This result is in line with similar findings by Guerzoni and Raiteri (2015), but conflicts with previous analyses on Flemish firms by Aerts and Schmidt (2008), Czarnitzki and Lopes-Bento (2013), or Hottenrott et al. (2014). Although Dumont (2017) finds some indication that Belgian subsidies have a small but positive impact, the effect may not be robust to different estimation techniques accounting for selection of firms into treatment. Moreover, as he uses a longer panel for subsidies, results could be driven by effects of grants received before tax credits were introduced in their current form in 2006. ${ }^{\text {xviii }}$ The three studies on Flemish firms, on the other hand, do not control for possible 'hidden treatment' effects - such as the use of tax credits alongside subsidies. Guerzoni and Raiteri (2015) show that failure to account for this issue can bias estimates by increasing the apparent treatment effect of the observed policy.The ATT estimators are partially robust to this bias by controlling for the simultaneous use of subsidies and wagebased tax credits. However, other support measures available to Belgian firms are not accounted for, such as tax credits for new R\&D investments, patent boxes, European subsidies or public procurement, all of which have been shown to affect private R\&D (see e.g. Czarnitzki \& Lopes-Bento, 2014; Guerzoni \& Raiteri, 2015). Instrumental variable estimations ensure more robustness against hidden treatment bias, if the IV assumptions hold.

Second, I find that subsidies can increase private R\&D spending if they are used together with tax credits and vice-versa, concluding that there is some interaction between the two policies. Similar effects are found by Guerzoni and Raiteri (2015). Tax credits, whether used 
separately or together, increase $R \& D$ spending of firms and substantially outperform subsidies, confirming a part of existing evidence (Carboni, 2011; Haegeland \& Møen, 2007b). Moreover, combining tax credits and subsidies in a policy mix further increasesprivate R\&Dspending, excluding complete substitution effects between the two policies.

Third, I show that the two policies have different action zones in terms of firms' expenditure on basic and applied research and development. Subsidies show a positive effect on basic and applied research only in combination with tax credits, but do not impact development activities. Tax credits, on the other hand, are more potent and increase all categories of R\&D whether used in isolation or combined. Like the effects on total expenditure, the policy mix also shows higher effects than subsidies or tax credits alone. An interesting finding is that using grants or the policy mix changes the way firms behave in their R\&D. I find evidence of an effect of turning firms away from development and towards research.

Fourth, my results also complement recent analyses by comparing the impact of policy through two estimation techniques. Similarly to Guerzoni and Raiteri (2015), I find that parametric estimators point to less stringent effects than non-parametric methods. This result may point to a possible upward bias driven by selection on unobservable. In other words, there might be company or project characteristics that matter in authorities' choice of subsidy recipients, but that are unobserved by the researcher. As more econometric evidence of policy impact is being produced, such method effect should always be addressed.

The key takeaway for policy makers is that wage-based tax credits seem to outperform subsidies in increasing private R\&D. Even though - contrary to subsidy recipients - firms benefitting from the wage-based tax credit are not restricted in the destination of the resources made available by the measure, the analysis points to increased investment in R\&D activities. This result suggests that market forces work towards more research and development, once funding barriers are lowered. On the other hand, one cannot conclude that subsidies should be scrapped from the support system altogether. Not only do they seem to positively interact with tax credits and create an increased effect on private R\&D through the policy mix, but they also may serve complementary purposes - for example providing aid to specific industries, regions or types of firms that require it at a given point.

\section{ACKNOWLEDGEMENTS}

Financial support from HU Brussels (PhD grant ZKC7171) is gratefully acknowledged.

I would like to thank the Belgian Federal Public Service Finance for providing the data used in this paper. I also want to thank the editor of this journal and the anonymous reviewers, as well as Stijn Kelchtermans, Reinhilde Veugelers, Peter Teirlinck, Pierre Mohnen and Albert Banal-Estañol for their very helpful comments. Early versions of this paper were presented at the Concordi conference in October 2015 in Seville, Spain, and included in the PhD thesis of the author.

\section{REFERENCES}

Aerts, K., \& Schmidt, T. (2008). Two for the price of one? Additionality effects of R\&D subsidies: A comparison between Flanders and Germany. Research Policy, 37(5), 806-822.

Aranguren, M. J., de la Maza, X., Parrilli, M. D., Vendrell-Herrero, F., \& Wilson, J. R. (2014). Nested Methodological Approaches for Cluster Policy Evaluation: An 
Application to the Basque Country. Regional Studies, 48(9), 1547-1562. https://doi.org/10.1080/00343404.2012.750423

Bérubé, C., \&Mohnen, P. (2009). Are firms that receive R\&D subsidies more innovative? Canadian Journal of Economics / Revue Canadienne D'économique, 42(1), 206-225.

Blanes, J. V., \&Busom, I. (2004). Who participates in R\&D subsidy programs? The case of Spanish manufacturing firms. Research Policy, 33(10), 1459-1476.

Busom, I., Corchuelo, B., \& Martínez-Ros, E. (2014). Tax incentives or subsidies for business R\&D? Small Business Economics, 43(3), 571-596. https://doi.org/10.1007/s11187-0149569-1

Carboni, O. A. (2011). R\&D subsidies and private R\&D expenditures: evidence from Italian manufacturing data. International Review of Applied Economics, 25(4), 419-439.

Castellacci, F., \& Lie, C. M. (2015). Do the effects of R\&D tax credits vary across industries? A meta-regression analysis. Research Policy, 44(4), 819-832.

Cerulli, G., \&Potì, B. (2012). Designing ex-post assessment of corporate RDI policies: conceptualisation, indicators and modelling. World Review of Science, Technology and Sustainable Development, 9(2-4), 96-123.

Clausen, T. H. (2009). Do subsidies have positive impacts on R\&D and innovation activities at the firm level? Structural Change and Economic Dynamics, 20(4), 239-253.

Corchuelo, B., \& Martínez-Ros, E. (2009). The Effects of Fiscal Incentives for R\&D in Spain. Business Economic Series 02, Universidad Carlos III de Madrid, WP 09-23. Retrieved from http://orff.uc3m.es/handle/10016/3870

Czarnitzki, D., Hanel, P., \& Rosa, J. M. (2011). Evaluating the impact of R\&D tax credits on innovation: A microeconometric study on Canadian firms. Research Policy, 40(2), 217-229. https://doi.org/10.1016/j.respol.2010.09.017

Czarnitzki, D., \&Hottenrott, H. (2011). R\&D investment and financing constraints of small and medium-sized firms. Small Business Economics, 36(1), 65-83.

Czarnitzki, D., Hottenrott, H., \&Thorwarth, S. (2011). Industrial research versus development investment: the implications of financial constraints. Cambridge Journal of Economics, $35(3), 527-544$.

Czarnitzki, D., \&Licht, G. (2006). Additionality of public R\&D grants in a transition economy. Economics of Transition, 14(1), 101-131.

Czarnitzki, D., \& Lopes-Bento, C. (2013). Value for money? New microeconometric evidence on public R\&D grants in Flanders. Research Policy, 42(1), 76-89. https://doi.org/10.1016/j.respol.2012.04.008

Czarnitzki, D., \& Lopes-Bento, C. (2014). Innovation subsidies: Does the funding source matter for innovation intensity and performance? Empirical evidence from Germany. Industry and Innovation, 21(5), 380-409.

David, P. A., Hall, B. H., \& Toole, A. A. (2000). Is public R\&D a complement or substitute for private R\&D? A review of the econometric evidence. Research Policy, 29(4-5), 497-529. https://doi.org/10.1016/S0048-7333(99)00087-6

Duguet, E. (2004). Are R\&D subsidies a substitute or a complement to privately funded R\&D? Revue D'économiePolitique, 114(2), 245-274.

Duguet, E. (2012). The effect of the incremental R\&D tax credit on the private funding of $\mathrm{R} \& \mathrm{D}$ an econometric evaluation on french firm level data. Revue D'économie Politique, 122(3), 405-435.

Dumont, M., Spithoven, A., \&Teirlinck, P. (2015). Public Support for R\&D and the Educational Mix of R\&D Employees. CESifo Economic Studies. https://doi.org/10.1093/cesifo/ifv017

Dumont, M. (2017). Assessing the policy mix of public support to business R\&D. Research Policy, 46(10), 1851-1862. 
Flanagan, K., Uyarra, E., \&Laranja, M. (2011). Reconceptualising the 'policy mix' for innovation. Research Policy, 40(5), 702-713. https://doi.org/10.1016/j.respol. 2011.02.005

García-Quevedo, J. (2004). Do public subsidies complement business R\&D? A meta-analysis of the econometric evidence. Kyklos, 57(1), 87-102.

Gerfin, M., \&Lechner, M. (2002). A Microeconometric Evaluation of the Active Labour Market Policy in Switzerland*. The Economic Journal, 112(482), 854-893.

González, X., \&Pazó, C. (2008). Do public subsidies stimulate private R\&D spending? Research Policy, 37(3), 371-389. https://doi.org/10.1016/j.respol.2007.10.009

Görg, H., \&Strobl, E. (2007). The effect of R\&D subsidies on private R\&D. Economica, 74(294), 215-234.

Guerzoni, M., \&Raiteri, E. (2015). Demand-side vs. supply-side technology policies: Hidden treatment and new empirical evidence on the policy mix. Research Policy, 44(3), 726-747.

Haegeland, T., \&Møen, J. (2007a). Input additionality in the Norwegian R\&D tax credit scheme (Statistics Norway Reports Series No. 47).

Haegeland, T., \&Møen, J. (2007b). The relationship between the Norwegian $R \& D$ tax credit scheme and other innovation policy instruments (Statistics Norway Reports Series No. 45).

Hall, B. H., \& Maffioli, A. (2008). Evaluating the impact of technology development funds in emerging economies: evidence from Latin America. The European Journal of Development Research, 20(2), 172-198.

Hall, B., \& Van Reenen, J. (2000). How effective are fiscal incentives for R\&D? A review of the evidence. Research Policy, 29(4-5), 449-469. https://doi.org/10.1016/S00487333(99)00085-2

Heckman, J. J., LaLonde, R. J., \& Smith, J. A. (1999). The economics and econometrics of active labor market programs. Handbook of Labor Economics, 3, 1865-2097.

Hottenrott, H., Lopes Bento, C., \& Veugelers, R. (2014). Direct and cross-scheme effects in a research and development subsidy program. Retrieved from http://papers.ssrn.com /sol3/papers.cfm?abstract_id=2506017

Ientile, D., \&Mairesse, J. (2009). A Policy to Boost the R\&D: Does the Tax Credit Work? European Investment Bank Paper, 14(1).

Lichtenberg, F. R. (1987). The effect of government funding on private industrial research and development: a re-assessment. The Journal of Industrial Economics, 97-104.

Lokshin, B., \&Mohnen, P. (2012). How effective are level-based R\&D tax credits? Evidence from the Netherlands. Applied Economics, 44(12), 1527-1538.

Mansfield, E. (1991). Academic research and industrial innovation. Research Policy, 20(1), 112.

Marino, M., Lhuillery, S., Parrotta, P., \& Sala, D. (2016). Additionality or crowding-out? An overall evaluation of public R\&D subsidy on private R\&D expenditure. Research Policy, 45(9), 1715-1730. https://doi.org/10.1016/j.respol.2016.04.009

Martin, B. R. (2016). R\&D policy instruments - a critical review of what we do and don't know. Industry and Innovation, 23(2), 157-176.

Montmartin, B., \& Herrera, M. (2015). Internal and external effects of R\&D subsidies and fiscal incentives: Empirical evidence using spatial dynamic panel models. Research Policy, 44(5), 1065-1079.

Neicu, D., Kelchtermans, S., \& Teirlinck, P. (2016). Thanks, but no thanks: Companies' response to $R \& D$ tax credits (MSI Working Papers - FEB Research Reports No. MSI 1608). Leuven, Belgium: University of Leuven. 
Neicu, D., Teirlinck, P., \& Kelchtermans, S. (2016). Dipping in the policy mix: Do R\&D subsidies foster behavioral additionality effects of R\&D tax credits? Economics of Innovation and New Technology, 25(3), 218-239. https://doi.org/10.1080/10438599. 2015.1076192

Rosenberg, N. (1990). Why do firms do basic research (with their own money)? Research Policy, 19(2), 165-174.

Rubin, D. B. (1977). Assignment to Treatment Group on the Basis of a Covariate. Journal of Educational and Behavioral Statistics, 2(1), 1-26.

Takalo, T., \& Tanayama, T. (2010). Adverse selection and financing of innovation: is there a need for R\&D subsidies? The Journal of Technology Transfer, 35(1), 16-41.

Wallsten, S. J. (2000). The effects of government-industry R\&D programs on private R\&D: the case of the Small Business Innovation Research program. The RAND Journal of Economics, 82-100.

Westmore, B. (2013). R\&D, Patenting and Growth: The Role of Public Policy (OECD Economics Department Working Papers No. 1047). OECD.

\section{APPENDIX}

Table 6. Multinomial probit estimation of treatment categories

\begin{tabular}{|l|r|r|r|}
\hline & MIX & SUBS & \multicolumn{1}{r|}{ TAX } \\
\hline LN AGE & $a$ & $b$ & $-0.39^{* * * *}$ \\
& $-0.52^{* * * *}$ & -0.12 & $(0.07)$ \\
\hline LN EMP & $(0.09)$ & $(0.09)$ & $0.34^{* * *}$ \\
& $0.34^{* * * *}$ & -0.06 & $(0.04)$ \\
\hline SME & $(0.05)$ & $(0.05)$ & -0.21 \\
& $-0.62^{* * *}$ & -0.36 & $(0.18)$ \\
\hline CURR & $(0.21)$ & $(0.23)$ & 0 \\
& $0.01^{*}$ & -0.03 & $(0.01)$ \\
\hline LN CAPINT & $(0.01)$ & $(0.02)$ & $0.12^{* * *}$ \\
& $0.16^{* * *}$ & $0.09^{* * *}$ & $(0.03)$ \\
\hline HITECH M & $(0.03)$ & $(0.03)$ & $0.53^{* *}$ \\
& $1.03^{* * *}$ & $0.79^{* * *}$ & $(0.23)$ \\
\hline HITECH S & $(0.3)$ & $(0.25)$ & $0.70^{* * *}$ \\
& $0.99^{* * *}$ & $0.63^{* *}$ & $(0.23)$ \\
\hline LOWTECH M & $(0.3)$ & $(0.25)$ & 0.02 \\
& -0.07 & 0.11 & $(0.22)$ \\
\hline LOWTECH S & $(0.31)$ & $(0.25)$ & 0.32 \\
& 0.16 & 0.29 & $(0.24)$ \\
\hline FLANDERS & $(0.32)$ & $(0.26)$ & 0.18 \\
& $0.38^{*}$ & 0.31 & $(0.17)$ \\
\hline WALLONIA & $(0.22)$ & $(0.22)$ & 0.31 \\
& $-0.58^{* * *}$ & $-0.54^{* *}$ & $(0.19)$ \\
\hline 2009 & $(0.25)$ & $(0.26)$ & $0.55^{* * *}$ \\
& 0.11 & $-0.38^{* * *}$ & $(0.1)$ \\
\hline 2011 & $(0.1)$ & $(0.12)$ & $0.83^{* * *}$ \\
& $0.36^{* * *}$ & -0.14 & $(0.1)$ \\
\hline Wald chi-square & $(0.1)$ & $(0.11)$ & \\
\hline
\end{tabular}

a) Base category are unsupported firms.

b) Robust standard errors clustered by firm.

c) $* * *, * *$, and $*$ indicate significance levels of $1 \%, 5 \%$ and $10 \%$, respectively.

d) Intercept term included but not shown. 
Table 7. First stage of 2SLS estimations

\begin{tabular}{|c|c|c|c|c|c|}
\hline & $\begin{array}{c}\text { LN TAX } \\
a\end{array}$ & $\begin{array}{c}\text { LN SUBS } \\
b\end{array}$ & $\begin{array}{c}\text { LN MIX } \\
c\end{array}$ & $\underset{d}{\text { LN TAX ONLY }}$ & $\begin{array}{c}\text { LN SUBS ONLY } \\
e\end{array}$ \\
\hline LN AVG MIX & & & $\begin{array}{r}0.24^{* * * *} \\
(0.02)\end{array}$ & $\begin{array}{r}-0.16^{* * *} \\
(0.02) \\
\end{array}$ & $\begin{array}{r}-0.12^{* * * *} \\
(0.02) \\
\end{array}$ \\
\hline NR MIX USERS & & & $\begin{array}{r}0.71^{* * * *} \\
(0.10)\end{array}$ & $\begin{array}{l}-0.18^{* *} \\
(0.08)\end{array}$ & $\begin{array}{r}-0.15^{* *} \\
(0.07)\end{array}$ \\
\hline LN AVG TAX & $\begin{array}{l}0.50^{* * * *} \\
(0.02)\end{array}$ & $\begin{array}{r}-0.03 \\
(0.02)\end{array}$ & $\begin{array}{r}0.02 \\
(0.01)\end{array}$ & $\begin{array}{r}0.46^{* * * *} \\
(0.02)\end{array}$ & $\begin{array}{r}-0.08^{* * * *} \\
(0.02)\end{array}$ \\
\hline NR TAX USERS & $\begin{array}{l}0.06^{* * *} \\
(0.02)\end{array}$ & $\begin{array}{r}-0.11^{* * * *} \\
(0.02)\end{array}$ & $\begin{array}{r}-0.15^{* * *} \\
(0.03)\end{array}$ & $\begin{array}{r}0.13^{* * * *} \\
(0.02)\end{array}$ & $\begin{array}{r}-0.05^{* * * *} \\
(0.01)\end{array}$ \\
\hline LN AVG SUBS & $\begin{array}{c}-0.01 \\
(0.02)\end{array}$ & $\begin{array}{r}0.36^{* * * *} \\
(0.02)\end{array}$ & $\begin{array}{c}0.10^{* * * *} \\
(0.01)\end{array}$ & $\begin{array}{r}-0.14^{* * * *} \\
(0.02)\end{array}$ & $\begin{array}{r}0.20^{* * * *} \\
(0.02)\end{array}$ \\
\hline NR SUBS USERS & $\begin{array}{r}-0.07^{* *} \\
(0.03)\end{array}$ & $\begin{array}{r}0.18^{* * * *} \\
(0.03)\end{array}$ & $\begin{array}{r}-0.23^{* * * *} \\
(0.04)\end{array}$ & $\begin{array}{l}-0.07^{*} \\
(0.04)\end{array}$ & $\begin{array}{r}0.18^{* * * * *} \\
(0.04)\end{array}$ \\
\hline LN AGE & $\begin{array}{r}-1.00^{* * * *} \\
(0.18)\end{array}$ & $\begin{array}{r}-0.55^{* * *} \\
(0.17)\end{array}$ & $\begin{array}{r}-0.52^{* * *} \\
(0.16)\end{array}$ & $\begin{array}{r}-0.49^{* * * *} \\
(0.15)\end{array}$ & $\begin{array}{r}0.02 \\
(0.09)\end{array}$ \\
\hline LN EMP & $\begin{array}{l}1.13^{* * * *} \\
(0.10)\end{array}$ & $\begin{array}{r}0.29^{* * * *} \\
(0.10)\end{array}$ & $\begin{array}{r}0.52^{* * * *} \\
(0.08)\end{array}$ & $\begin{array}{r}0.60^{* * * *} \\
(0.08)\end{array}$ & $\begin{array}{r}-0.20^{* * * *} \\
(0.06)\end{array}$ \\
\hline SME & $\begin{array}{r}-1.06^{* *} \\
(0.43)\end{array}$ & $\begin{array}{r}-2.16^{* * * *} \\
(0.42)\end{array}$ & $\begin{array}{r}-1.36^{* * *} \\
(0.41)\end{array}$ & $\begin{array}{r}0.47 \\
(0.39)\end{array}$ & $\begin{array}{r}-0.62^{* * * *} \\
(0.22)\end{array}$ \\
\hline LEVER & $\begin{array}{r}0.00 \\
(0.00) \\
\end{array}$ & $\begin{array}{r}-0.00^{* * * *} \\
(0.00) \\
\end{array}$ & $\begin{array}{r}-0.00^{* * * *} \\
(0.00) \\
\end{array}$ & $\begin{array}{r}0.00^{* * * *} \\
(0.00)\end{array}$ & $\begin{array}{r}0.00 \\
(0.00) \\
\end{array}$ \\
\hline CURR & $\begin{array}{r}0.02 \\
(0.03)\end{array}$ & $\begin{array}{r}0.03 \\
(0.02)\end{array}$ & $\begin{array}{r}0.03 \\
(0.02)\end{array}$ & $\begin{array}{r}-0.01 \\
(0.01)\end{array}$ & $\begin{array}{r}-0.00 \\
(0.01) \\
\end{array}$ \\
\hline LN CAPINT & $\begin{array}{r}0.34^{* * * *} \\
(0.08)\end{array}$ & $\begin{array}{r}0.35^{* * *} \\
(0.07)\end{array}$ & $\begin{array}{r}0.24^{* * *} \\
(0.06)\end{array}$ & $\begin{array}{r}0.10 \\
(0.07)\end{array}$ & $\begin{array}{l}0.08^{\text {** }} \\
(0.04)\end{array}$ \\
\hline HITECH M & $\begin{array}{r}0.73 \\
(0.47)\end{array}$ & $\begin{array}{l}1.09^{* *} \\
(0.48)\end{array}$ & $\begin{array}{r}-0.14 \\
(0.38)\end{array}$ & $\begin{array}{r}0.53 \\
(0.43)\end{array}$ & $\begin{array}{r}0.85^{* * * * *} \\
(0.27)\end{array}$ \\
\hline HITECH S & $\begin{array}{r}0.57 \\
(0.53)\end{array}$ & $\begin{array}{r}0.09 \\
(0.51)\end{array}$ & $\begin{array}{r}-0.43 \\
(0.41)\end{array}$ & $\begin{array}{l}0.97^{* *} \\
(0.48)\end{array}$ & $\begin{array}{r}0.48 \\
(0.31)\end{array}$ \\
\hline LOWTECH M & $\begin{array}{r}-0.37 \\
(0.45)\end{array}$ & $\begin{array}{r}-0.38 \\
(0.44)\end{array}$ & $\begin{array}{r}-0.79^{* *} \\
(0.33)\end{array}$ & $\begin{array}{r}0.27 \\
(0.41)\end{array}$ & $\begin{array}{r}0.23 \\
(0.24) \\
\end{array}$ \\
\hline LOWTECH S & $\begin{array}{r}0.29 \\
(0.49)\end{array}$ & $\begin{array}{r}0.27 \\
(0.46)\end{array}$ & $\begin{array}{r}-0.34 \\
(0.34)\end{array}$ & $\begin{array}{r}0.50 \\
(0.44)\end{array}$ & $\begin{array}{r}0.49^{*} \\
(0.26)\end{array}$ \\
\hline FLANDERS & $\begin{array}{r}-0.59 \\
(0.44)\end{array}$ & $\begin{array}{r}-0.87^{* *} \\
(0.42)\end{array}$ & $\begin{array}{l}-0.69^{*} \\
(0.38)\end{array}$ & $\begin{array}{r}0.16 \\
(0.37)\end{array}$ & $\begin{array}{r}-0.16 \\
(0.29)\end{array}$ \\
\hline WALLONIA & $\begin{array}{r}0.10 \\
(0.46)\end{array}$ & $\begin{array}{r}-1.68^{* * * *} \\
(0.39) \\
\end{array}$ & $\begin{array}{r}-1.04^{* * *} \\
(0.36) \\
\end{array}$ & $\begin{array}{l}1.15^{* * * *} \\
(0.40)\end{array}$ & $\begin{array}{r}-0.63^{* * *} \\
(0.28)\end{array}$ \\
\hline Obs. & 2650 & 2650 & 2650 & 2650 & 2650 \\
\hline Firms & 1809 & 1809 & 1809 & 1809 & 1809 \\
\hline
\end{tabular}

Source:

a) $* * *, * *$, and $*$ indicate significance levels of $1 \%, 5 \%$ and $10 \%$, respectively.

b) Robust standard errors clustered by firm.

c) Intercept term and year dummies included but not shown in table.

d) Base category for industry indicators comprises firms that do not fit in high- or low-tech groups. Base categories for region is Brussels.

e) Instruments include the number of users of each policy and average amount received by 4-digit NACE industries, year and size group.

iSee García-Quevedo (2004) for a meta-analysis of the impact of public funding on private R\&D.

ii A more thorough comparison with Neicu et al. (2016) follows at the end of section 2.

iii Most recent studies address in some way the selection bias, overcoming the issues signalled in David et al.(2000).See e.g. Cerulli\&Potì (2012) for a discussion on the methods of R\&D policy evaluation.

iv The dataset is a collection of data managed by the Belgian Federal Public Service Finance and collected from the following sources: the Belgian Federal Public Service Finance (tax credit data), the National Bank of 
Belgium (financial data), the Belgian Federal Science Policy Office (R\&D survey), and the regional agencies involved in R\&D subsidy allocation - the Walloon government's R\&D services, the Flemish governmental Agency for Innovation by Science and Technology (IWT) and the Institute for Scientific Research and Innovation of Brussels (IRSIB).

${ }^{v}$ Only around 220 firms have full data covering the three waves of the survey.

vi Only firms that have responded to the survey are analysed (estimated values by the Science Policy Office have been removed). Moreover, firms that report no internal $R \& D$ expenditure or a number that is higher than total costs (R\&D intensity higher than $100 \%$ ) are removed the sample for consistency.

viiThere might be instances where theoretical arguments can be made against the exogeneity of the instruments. For example, in a Cournot model, competitors' use of public support lowers their cost of R\&D and improves their competitive position. This, in turn, can have two effects: first, it can reduce incentives to engage in R\&D if these activities are strategic substitutes; on the other hand, if $R \& D$ results in innovations that lower the cost of production, increased investment in $R \& D$ is a competitive response. Both results illustrate that the instruments are possibly correlated with the outcome. Nevertheless, the issue is somewhat mitigated by the non-significant Hansen $\mathbf{J}$ tests. Under $\mathrm{H}_{0}$, all instruments are uncorrelated with the error term of the main equation. My estimations show that the null cannot be rejected at $10 \%$, which provides some assurance that the Cournot effects are minimal.

viii Note that it is entirely possible that a company that receives support increases its private expenditure on both research and development, but the increase is less for one category than the other; in this case, the effect of the support used by the firm would be positive on all log-level variables, but negative on either development or research intensity.

ix This definition of treatment is rather strict. An alternative would be to consider treatment over two-year periods - e.g. a policy mix user would have used tax credits and subsidies either in period $t$ or $t-1$, and not necessarily both at the same time. As matching estimators require that treated and control groups be balanced before treatment receipt, this would imply matching on observed characteristics in $t-2$, which would drastically reduce the data set by requiring to observe each firm in two consecutive surveys.

${ }^{x}$ The sample only includes firms that report positive intra-mural R\&D expenditure.

${ }^{x i}$ I calculate the Wald chi-square statistic of a probit on the binary variable indicating treatment receipt, where the sample includes only firms that have been matched. The statistic tests the balance between treated and control groups, the null being that the observed characteristics do not explain treatment receipt, i.e. groups are balanced on covariates.

xii The ATT is calculated as the difference in $\log$-levels $A T T=\ln \left(R \& D_{\text {treated }}\right)-\ln \left(R \& D_{\text {control }}\right)=$ $\ln \left(R \& D_{\text {treated }} / R \& D_{\text {control }}\right)$. Exponentiating gives the ratio of $\mathrm{R} \& \mathrm{D}$ spending of treated to that of control firms.

xiii Note that due to the different sizes of treatment groups and the fact that matching is done with replacement, the ATTs are not symmetrical - e.g. the difference between the policy mix treatment and the tax credits counterfactual is different than the tax credits treatment versus the policy mix counterfactual. However, the differences are small in absolute value (0.49 vs. 0.31). Because the tax credit users group is larger than the other two treatment groups, the ATTs calculated when this group is the counterfactual are more robust and thus preferred in the analysis.

${ }^{\text {xiv }}$ A categorical matching estimation of ATTs shows indeed that larger (than the median) amounts of either policy have the largest effects, and the policies are not significantly different from each other at large volumes. At smaller volumes, subsidies show no additionality on applied research.

${ }^{x v}$ An estimation of ATTs on the percentage of development activities, rather than the volume, confirms this conclusion. Results are available on demand.

xvi Note that average amount of policy mix received and number of users are not linear combinations of the average amounts of tax credits and subsidies and the number of users of each.

xviiTo assess whether subsidies and tax credits have different effects by firm size, I also estimate the same 2SLS models on two subsamples - one containing SMEs and another comprising large firms.Theresults, which are available on request,show that policies have similar effects on overall R\&D spending for SMEs and large firms. However, the former are more responsive to the policy mix in terms of basic research and also increase applied research spending when using any measure, while large firms are more varied in their responses across all three $\mathrm{R} \& \mathrm{D}$ activity types.

xviii Previous studies have shown that when the level of indirect R\&D support is raised, the incentive effect of direct support drops, and vice-versa (Montmartin \& Herrera, 2015, p. 1070). 